\section{The Fertility and Extinction of Forest Trees.}

THE mountains of Madeira exemplify perhaps more clearly than the denuded Scottish hills the "irreparable loss" which your correspondent "D. W. T." (NATURE, June I) deplores in the disappearance of the Scotch fir forests. For not only have we exhausted our splendid timber in prodigal excess of economic requirements, but we have further to face the fact that the straggling trees which still survive in remote or precipitous localities appear to have lost much of their former fertility, showing now no tendency to spontaneous spread nor any evidence of the prolific reproduction of former days. Hence we are confronted with the absolute extinction of woods not grown elsewhere-woods of very great botanic interest both in themselves and in relation to problems of origin and distribution.

Madeira (Materia) was the name given criginally by the Portuguese discoverers to denote the densely wooded condition of their new possession.

The destruction of the forests began with the first colonists nearly 500 years ago, and was accentuated during the Spanish occupation in the second century of the island history. No replanting whatever has been attempted since, nor have any effective measures been put in force to stay the progress of destruction. The island population, moreover, has increased during the last fifty years from 75,000 to 150,000 people, and the land is everywhere being cleared and occupied.

Nevertheless, the introduction of the Pinus Pinaster has 'during the last 150 years had an important influence on the preservation of the surviving native vegetation, and the tree has become established on the heights from I 500 feet to 3000 feet above the sea in surprising vigour and profusion, supplying fuel and many requirements on which a more durable and valuable wood would be wasted. Some of your readers have seen at my mountain home the stately growth of the Pinaster planted only sixty years ago. The larger trees have a girth, 5 feet above the ground, of 12 to $I_{5}$ feet, and vary from 80 to 130 feet in height. They lose all their lower branches in due course, many of them standing in majestic isolation to suggest the famous "Spear, to equal which the tallest pine hewn on Norwegian hills to be the mast of some great ammiral were but a wand." These Pinasters were giants when I came into possession thirty-five years ago, and their growth since has been in girth rather than in altitude, though their heads have not yet reached the Ezekiel stage of your correspondent " D. W. T."

In my view we should not trust to the maintenance of a single species in vigour and fertility, and hence I have brought many coniferous and other trees hither to test both quality and rate of growth, and thus their fitness to supplement or supplant our present supplies. Many of the newcomers, though growing into beautiful examples, do not merit extensive plantation, and I have not raised any specimens of Podocarpus, Widdringtonia, Libocedrus, Dacrydium, \&c., the merits of which encourage their multiplication; but it is far otherwise with the Douglas fir, the Taxodium sempervirens, the Abies Pinsapo, Cupressus macrocarpa, \&c., which are quite at home in their new environment and congenial soil, as also with the Pinus canariensis and the $P$. longifolia. The $P$. insignis, however, in this latitude is pre-eminently worthy of general adoption at the elevation of 2000 feet. I received seeds of this species from Kew in Sir J. Hooker's time, and one of the trees from this source has attained a growth of more than roo feet in twenty-six years; and I have a goodly patch of young trees sown ten years ago which already vary from 25 to 30 feet in height.

But I have written enough to illustrate the importance of planting new varieties when threatened with declining fertility or extinction, though I cannot think the Pinus silvestris to be in any such danger. Irreparable loss is mainly the result of improvidence.

It is interesting to note that many of the Madeira trees which have become nearly sterile and almost extinct in the wild state become vigorous and abundantly fertile in cultivated ground.

The Cerasus lusitanica, the weeping Juniper ( $J$. Oxycedrus), Phoebe barbusana, \&c., are familiar examples of reviving fertility in altered circumstances.

NO. 2 I 84 , VOT. 87 ]
I have sent from time to time specimens of the Madeira rare woods to the museum at Kew, and amongst them the ebony-like laurel wood of the Oreodaphne foetens, the heavy oleaceous wood of the Notaelea excelsa, and a long hammock-carrying pole made of Clethra wood, are worth attention.

The Clethra arborea is happily still quite common, and attractive at this season with its abundant show of fragrant lily-of-the-valley-like flowers.
Madeira, August $2 \mathrm{I}$.
Michael Grabham.

\section{Non-Euclidean Geometry.}

IN my "Theories of Parallelism" I expressed my sense of failure in controverting Bertrand's simple proof (by the consideration of infinite sectors and infinite strips) of Euclid's parallel axiom. This sense of failure has only increased since the publication of my little book.

I have also come across the statement that Poincaré has proved that no Beltrami "trumpet" surface in Euclidean space can completely image a hyperbolic space unless it has a line of discontinuity on it. I would welcome definite information about this. It seems to me an important objection. Had Poincaré this at the back of his mind when he dismissed space-theories as matters of convenience only in his brilliant volume "La Science et I'Hypothèse "?

There is something passing strange about the infinite regions of a hyperbolic space. If $\mathrm{K}$ is the space-constant and $R$ the radius of a circle in Lobachewskian space, and if $R$ is exceedingly large even compared with $K$, then the area of the circle appears as an exponential infinitude, something like $\pi \mathrm{K}^{2} \rho^{\mathrm{K}}$

But if a regular polygon with an indefinitely great number of sides ( $N$, say) can be inscribed in this circle of radius $\mathrm{R}$, the area of each of the $\mathrm{N}$ component triangles is only $\mathrm{K}^{2}$ times the divergence. And the divergence of each triangle cannot very well be supposed to exceed $2 \pi$. for then the angle-sum would be $3 \pi$. Hence the area of the polygon appears less than $2 \pi \mathrm{K}^{2} \mathrm{~N}$

Would readers offer an opinion?

Wrawby, near Brigg.

W. B. FRANKLAND.

\section{The Salary of an Assistant Lecturer.}

I HAVE read with indignation the advertisement of the City of Bradford Education Committee on p. lxiv of NATURE of August 17 for an assistant lecturer in dyeing at a salary of " 6ol. per annum, with additional payment for evening work (two evenings per week)."

Do the members of this committee realise that they are offering to an assistant lecturer at their college less than the minimum wages-24s. a week-demanded by the railway strikers in the North for the lowest and least efficient railway employee?

They may reply that their lecturer can make a little more by extra work-evening work; but so can the railway employee, and the latter may do it without doing any extra work whatever.

According to the conditions of appointment, the person appointed will be required to devote the whole of his time to college work; the hours of actual attendance at the college are thirty-seven per week, the vacations may be curtailed "if necessity demands it," and the amount of the payment for the evening work is not given.

Tredethlyn, Port Isaac, Cornwall, August 22.

$$
\text { W. H. HodGSON. }
$$

\section{Obsolete Botanical and Zoological Systems.}

IN reply to the request of L. C. M. in your issue of August 3, the following references may be of interest to him. "Insect Architecture," Charles Knight and Co., Ludgate Street, 1845 , contains a chapter upon systematic arrangement of insects, which contains the following:Aristotle's, Linnæus's, De Geer's, Aldrovand's, Vallisnieri's, Fabricius's, Latrielle's, Swammerdam's, Ray and Willughby's, Cuvier's, Lamarck's, Sir Everard Home's, Clairville's, Leach's, Stephen's, and McLeay's classifications. Hoping this may be of use. M. Niblett. 52 Oxford Road, Chesterton, Cambridge. 